\title{
Impact of Assembly Method on the Strength of Single-Lap Joints of Aircraft Aluminum Alloy Sheets
}

\author{
Izabela Miturska
}

\author{
1 Faculty of Mechanical Engineering, Lublin University of Technology, Nadbystrzycka 36, 20-618 Lublin, Poland \\ e-mail: i.miturska@pollub.pl
}

\begin{abstract}
The paper presents a comparative analysis of the strength properties of single-lap assembly joints. Single-lap joints are commonly used in various structures because of their strength properties. Three types of joints, widely used in modern structures, were prepared and tested: adhesive, rivet, and hybrid adhesive-rivet joints. The experiments were carried out using aluminum alloy EN AW-2024, a structural material used in aviation. In the adhesive joints, the substrates were joined using a two-component epoxy adhesive composed of Epidian 53 epoxy resin and polymide curing agent (PAC) - Epidian 53/PAC/100:80. The rivet joints were formed using steel-aluminum blind rivets. The rivets were arranged in four different configurations. One of the very important structural factors considered when designing single-lap assembly joints is overlap length. In the present study, two overlap lengths were tested: $12 \mathrm{~mm}$ and $20 \mathrm{~mm}$. The assembly joints were subjected to strength tests. Tensile-shear strength was determined. The results were analyzed statistically.
\end{abstract}

Keywords: adhesive joints, rivet joints, hybrid joints, epoxy adhesive, aluminum sheets

\section{INTRODUCTION}

Assembly joints are essential elements in the design and construction of all kinds of structures. As a result of joining, the individual structural components are bonded together, which allows them to carry loads. Depending on whether the components are joined using a fastener or not, joints are divided into indirect and direct ones. A fastener can be a screw, a rivet, a cotter pin, a stud, a pin and others. These elements most often cut through the contact plane of the joining members. In turn, direct joints are produced by forming the joining parts $[3,4]$. Assembly joints can also be classified in terms of their structural features as separable and inseparable [2]. The choice of an appropriate type of joint is usually dictated by numerous factors, such as the type of materials to be joined, joining requirements, operating conditions, etc $[2,14,15]$. The focus of the present study were adhesive, rivet, and adhesive-rivet joints used to fasten EN AW-2024-T3 aluminum alloy sheets.
Adhesive bonding is a method of forming permanent joints. Current progress in the quality of adhesives allows to use adhesive joints in many primary aircraft, marine, and automotive structures and in machine construction $[9,10,16]$. Adhesive joints have many advantages; among others, they dampen vibrations, have a sealing effect, and can be used to bond various types of (dissimilar) materials $[5,7]$. The most commonly used and the most advantageous adhesive joints are lap joints. Their popularity is associated with their high shear strength. The main problem that has to be considered in forming such joints is the fact that they are exposed to non-axial loading. In such structures, in addition to tangential stresses, additional tensile stresses occur, which are directed perpendicular to the adhesive layer. These problems can be solved by using rivets to press down the adherends. Riveting helps reduce the negative impact of peel stress. The resultant hybrid joint is a product of combination of two commonly used joining technologies: adhesive bonding and riveting. The combined technology 
uses the advantages of the two base technologies, while eliminating the numerous disadvantages that characterize each of these processes separately. In the present study, experiments were carried out to test and compare the possibilities offered by adhesive bonding, riveting and a combination of these two techniques. To this end, strength tests and a comparative analysis of test results were performed.

\section{MATERIALS AND METHODS}

\section{Material}

The joints under investigation were made of EN AW-2024-T3 aluminum alloy sheets. Aluminum alloy joints are commonly used in aviation, construction and engineering. Alloy EN AW2024-T3 has a very low resistance to oxidation. It is most often used for the production of aircraft equipment, gears and shafts, screws, computer parts, clutches, parts of hydraulic valves, parts of rockets and ammunition, worm gears as well as orthopedic equipment. It is used wherever there is no risk of corrosion. The chemical composition and properties of the sheet metal used are given in Tables 1 and 2 in accordance with the BS EN 4400-2: 2019 and PN-EN 573-1: 2006 standards.

The dimensions of the metal sheets used in the tests are given in Figure 1.

As indicated by its designation, aluminum alloy EN AW-2024-T3 used in the experiments is a tempered material: T3 means that the product had been solution heat treated and then cold worked [19].

\section{Test joints}

There are many structural and design factors that have an impact on the strength of assembly joints $[1,7,17]$. In adhesive joints, one such critical structural factor is the length of the joint $[6$, 8]. Some structures combine materials of different thickness and properties, which means the joints may have different mechanical properties. For many adhesively bonded joints, the length of the joint must be determined before a design is made as it affects the strength and cost-effectiveness of the connection. The overlap length should be such that it does not increase the strength of the joint. An adhesive joint can be appropriately designed when the optimal overlap length is known. Cost-effectiveness depends, among others, on the amount of adhesive used, especially when the joint has a large surface area. Most of the adhesives used in structural bonding are expensive, so overlap length must be a trade-off between cost and strength requirements. There is no reason for producing adhesively-bonded joints that are thicker or longer than optimal [12].

In connection with the above, two overlap lengths, $12 \mathrm{~mm}$ and $20 \mathrm{~mm}$, were tested for all three kinds of joints. Figure 2 shows a schematic of the investigated lap joints.

All the lap joints used in the strength tests had been $\mathrm{f}$ in laboratory conditions at a temperature of $23 \pm 2{ }^{\circ} \mathrm{C}$ and $42 \pm 3 \%$ air humidity.

Table 3 lists all single-lap joints prepared for the experiments.

The joint variants differed with regard to joint type, overlap length, and the way rivets were arranged. In total, 80 lap joints were made and tested in the present study.

\section{Preparation of joints}

Before bonding, the surfaces of the metal sheets (both in adhesive and adhesive-rivet joints) were prepared by machining with a P 280 grit grinding tool. The tool, moving in a circular path, was passed 30 times over the entire length of the overlap. After machining, the adherends were treated chemically to remove abrasive residues and impurities and to degrease the surfaces. The chemical treatment involved washing three times with technical acetone.

Adhesive and adhesive-rivet joints were formed using an epoxy adhesive composition consisting of Epidian 53 epoxy resin and PAC hardener. Epidian 53 resin is a mixture of epoxy resin, obtained from bisphenol A and epichlorohydrin (Epidian 5), and styrene. It has a low viscosity $\left(900-1500 \mathrm{mPas}\right.$ at $25^{\circ} \mathrm{C}$ ) and a lower density than Epidian $5\left(1.11-1.15 \mathrm{~g} / \mathrm{cm}^{3}\right.$ at $20^{\circ} \mathrm{C}$ ). Epidian 53 resin is characterized by a

Table 1. Chemical composition of aluminum alloy EN AW-2024 [20]

\begin{tabular}{|c|c|c|c|c|c|c|c|c|c|}
\hline Component & $\mathrm{Si}$ & $\mathrm{Fe}$ & $\mathrm{Cu}$ & $\mathrm{Mn}$ & $\mathrm{Mg}$ & $\mathrm{Cr}$ & $\mathrm{Zn}$ & $\mathrm{Ti}$ & $\mathrm{Zr}$ \\
\hline Percentage share, \% & 0.50 & 0.50 & $3.80-4.90$ & $0.30-0.90$ & $1.20-1.80$ & 0.10 & 0.25 & 0.15 & $<0.10$ \\
\hline
\end{tabular}


Table 2. Properties of aluminum alloy EN AW-2024 [18]

\begin{tabular}{|l|c|c|}
\hline \multicolumn{1}{|c|}{ Property } & Value & Unit \\
\hline Tensile strength & $360-435$ & $\mathrm{MPa}$ \\
\hline Yield strength & $250-290$ & $\mathrm{MPa}$ \\
\hline Hardness & $104-123$ & $\mathrm{HB}$ \\
\hline Elongation & $12-14$ & $\%$ \\
\hline Thermal conductivity & $130-170$ & $\mathrm{~W} / \mathrm{mK}^{-1}$ \\
\hline Density & 2.78 & $\mathrm{~g} / \mathrm{cm}^{3}$ \\
\hline
\end{tabular}

high shear strength at ca. $110{ }^{\circ} \mathrm{C}$ [11]. Compositions with this resin are used for joining glass laminates. Due to its excellent electrical and insulation properties, Epidian 53 can be used in radio-frequency engineering, aviation and optics. PAC hardener is a dense brown substance. It is used in joining elements prone to deformation, such as thin metal sheets. The addition of PAC hardener increases the impact strength and elasticity of adhesive joints. The resin and the hardener were mixed mechanically with a propeller stirrer at a rate of $460 \mathrm{rpm}$. Mixing time was 3 minutes. The adhesive composition was applied to one of the adherends using special equipment which helped ensure that the adhesive layer was evenly spread (had the same thickness) over the entire length of the overlap. The joints were then cured and seasoned under a constant load of $2 \mathrm{~kg}$ for a fortnight [13].

Rivet joints were formed using steel-aluminum blind rivets with steel mandrels. The dimensions of the rivets were: diameter $\mathrm{d}=4 \mathrm{~mm}$, length $1_{\mathrm{n}}=8 \mathrm{~mm}$.

The following technological steps were performed to produce the adhesive joints:

- prepare surfaces,

- prepare a two-component epoxy adhesive composition,

- apply the adhesive to one of the adherends,

- join the adherends, creating an overlap with a predetermined length and ensuring the axiality of the joined components,

- apply pressure

- season,

- perform visual control of joint quality.

The rivets in the rivet joints were set as specified in Table 3 in the following series of steps:

- clean the surfaces with technical acetone,

- lay out and center-punch rivet locations (in accordance with the design assumptions given in Table 3),

- drill holes for rivets with a ø $4.1 \mathrm{~mm}$ diameter drill,

- insert rivets in the holes and hold the members in place using a special locking clamp, making sure that the holes line up,

- set the rivets using a hand riveter,

- perform visual control of joint quality.

Adhesive-rivet joints were made using the following technology:

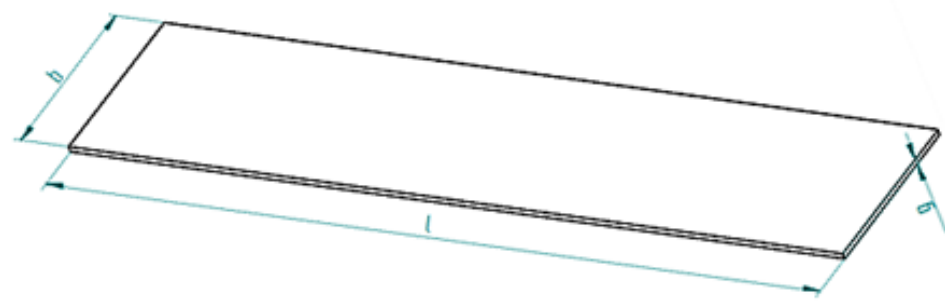

Fig. 1. Shape and dimensions of the metal sheets used in forming the adhesive, rivet and adhesive-rivet joints: Length $-1=100.00 \pm 0.5 \mathrm{~mm}$, width $-\mathrm{b}=20.00 \pm 0.5 \mathrm{~mm}$, thickness $-\mathrm{g}=0.65 \mathrm{~mm}$.
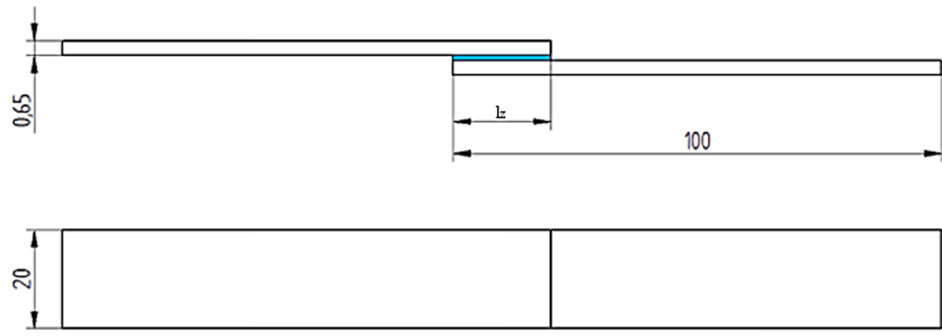

Fig. 2. Schematic of a lap joint 
Table 3. Number of joints made and the arrangement of rivets in rivet and adhesive-rivet joints

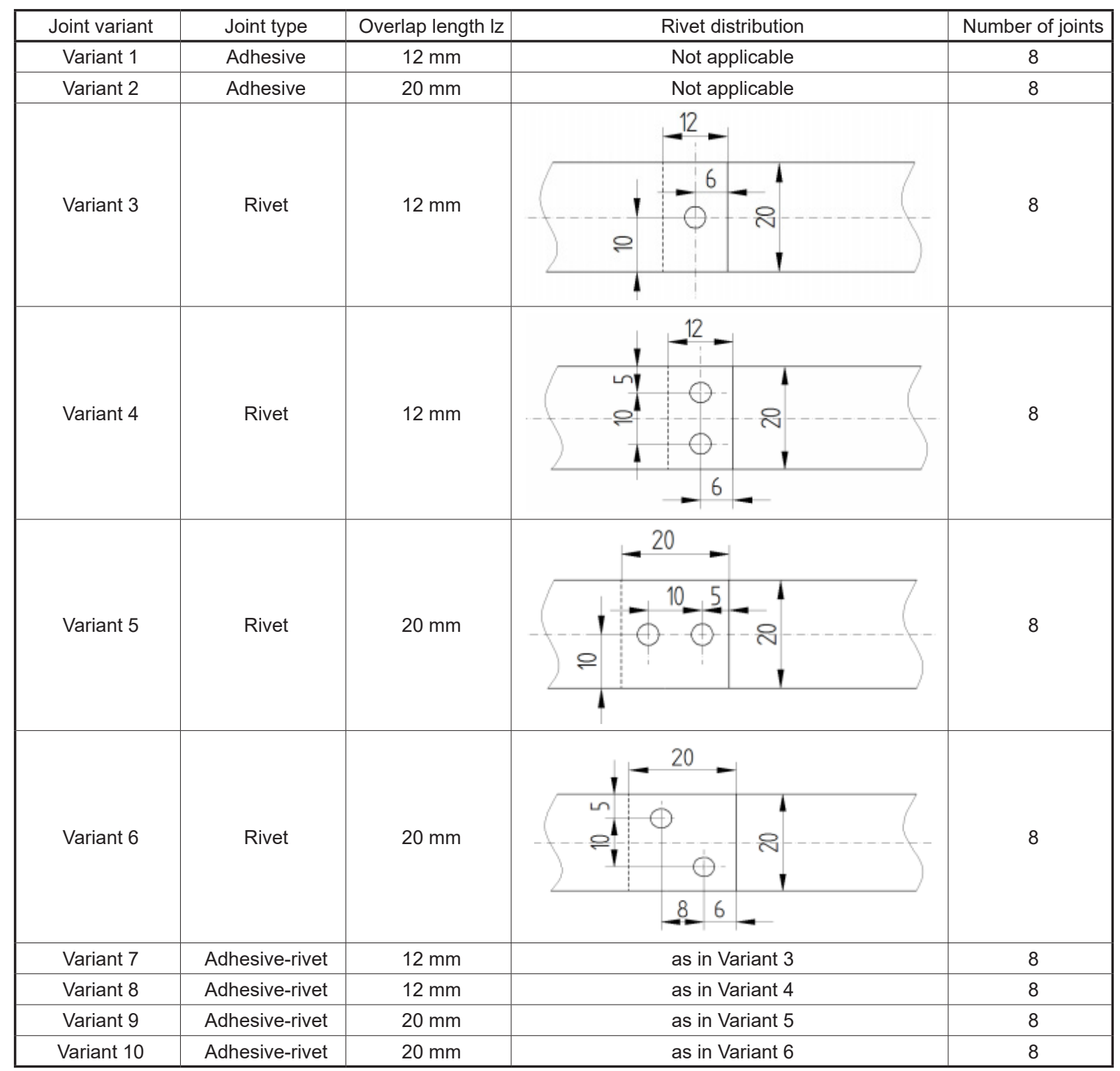

- join sheets, creating an overlap (as in the case of adhesive joints)

- lay out and center-punch rivet locations (in accordance with the design assumptions given in Table 3),

- make holes for rivets with a $\varnothing 4.1 \mathrm{~mm}$ drill,

- place rivets in the holes,

- set rivets,

- perform visual control of joint quality.

A schematic of an adhesive-rivet joint formed in accordance with the design assumptions (for variant 5) is shown in Figure 3.

After the adhesive and adhesive-rivet joints had been seasoned, all single-lap joints were subjected to strength tests. The tests were carried out on a Zwick/Roell Z150 tensile testing machine at an initial force of $20 \mathrm{~N}$ and a test speed of $20 \mathrm{~mm} / \mathrm{min}$, in accordance with the ISO 4587 standard. A tensile test was performed. The results were used to determine shear strength and assess the investigated joint-making technologies.

\section{RESULTS}

In this part we report and explain the results of the experiments, while the summary contains conclusions and observations based on the statistical analysis of these data; the statistical analysis itself is contained in the section below. The figures below show the results of strength tests of the investigated assembly joints made of EN AW 2024 aluminum alloy sheets for different 


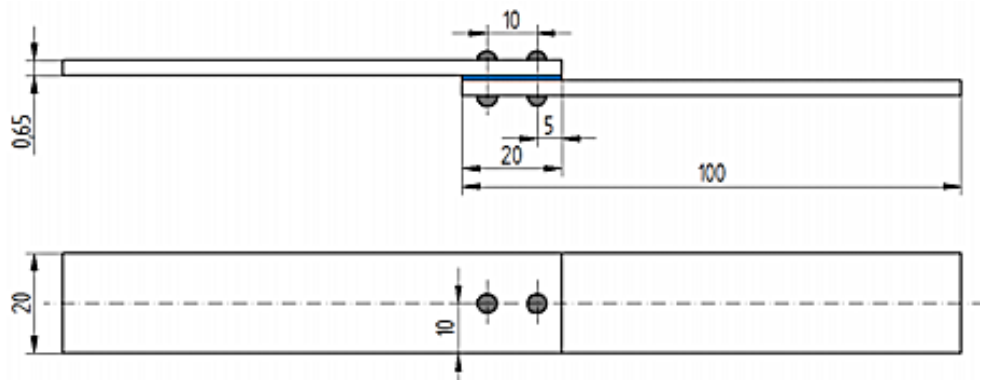

Fig. 3. Schematic of an adhesive-rivet joint (variant 5)

overlap lengths (Table 3). Joint strength was expressed as a ratio of mean shear stress $[\mathrm{N}]$ to bond area $\left[\mathrm{mm}^{2}\right]$.

Figure 4 presents mean shear strength values for adhesive joints formed by bonding EN AW-2024 aluminum sheets with the Epidian 53/ PAC/100: 80 adhesive composition. Mean shear strength was $4.25 \mathrm{MPa}$ for joints with an overlap length of $\mathrm{lz}=12 \mathrm{~mm}$ (variant 1 ), and 3.18 MPa for joints with an overlap length of $\mathrm{lz}=$ $20 \mathrm{~mm}$ (variant 1). The difference between the shear strengths of these two types of joints was $25 \%$. The repeatability of the results determined on the basis of standard deviation was $18 \%$ for variant 1 joints and $16 \%$ for variant 2 joints.
Figure 5 compares the mean shear strength values for all variants of rivet joints (with different overlap lengths and rivet arrangements). The highest strength of $4.94 \mathrm{MPa}$ was obtained for rivet joints with an overlap length of $\mathrm{lz}=$ $12 \mathrm{~mm}$ fastened with two transversely arranged rivets (variant 4). The lowest tensile strength of 1.95 $\mathrm{MPa}$ was observed for joints with one rivet (variant 3). The difference between maximum and minimum strength values was $60.5 \%$. In the case of the rivet joints with an overlap length of $\mathrm{lz}=20 \mathrm{~mm}$, variant 5 with two longitudinally arranged rivets turned out to be less satisfying strengthwise $(2.75 \mathrm{MPa})$. An analysis of standard deviations shows that the largest discrepancy

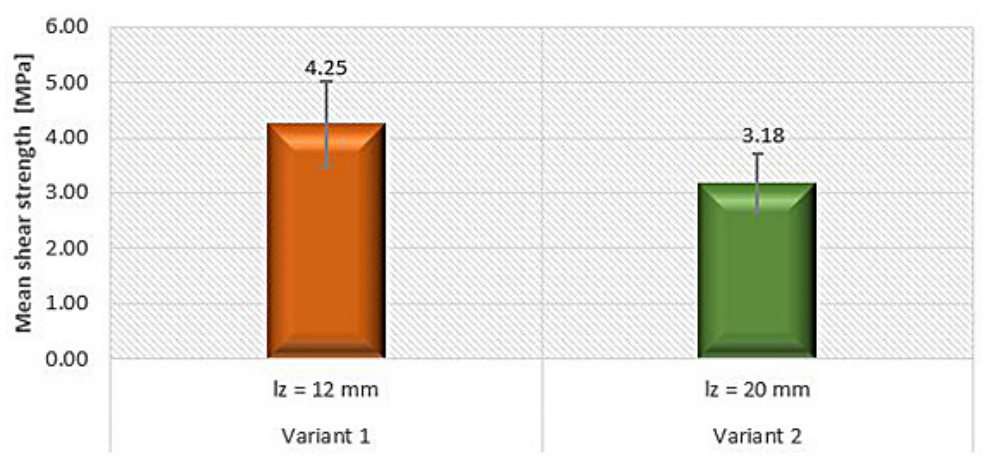

Fig. 4. Mean shear strength of adhesive joints by overlap length

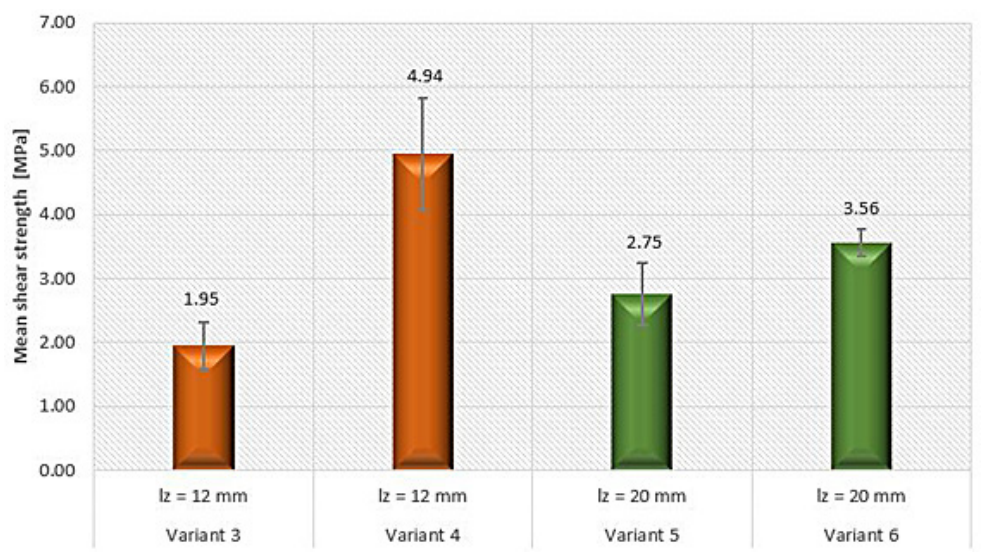

Fig. 5. Mean shear strength of riveted joints by overlap length 
between results (19.9\%) was found for variant 3. Variant 6 joints were characterized by the highest $(6.2 \%)$ repeatability of results.

Figure 6 compares shear strength values for adhesive-rivet joints. Among the four variants of adhesive-rivet joints, variant 9 , i.e. a joint with two longitudinally arranged rivets, had the highest strength (5.09 MPa). Variant 7 and variant 10 joints were characterized by the lowest strength. The strength values for these two variants were similar: $3.43 \mathrm{MPa}$ and $3.37 \mathrm{MPa}$, respectively. The difference between them was only $1.7 \%$. However, while variant 10 joints showed the highest repeatability of results with a standard deviation of $14.5 \%$, variant 7 was characterized by the largest discrepancy between results, with a standard deviation of $22.8 \%$.

A comparison of the strength properties of all the assembly joints tested in the present study shows that the highest shear strength characterized rivet joints with two transverse rivets and an overlap length of $\mathrm{lz}=12 \mathrm{~mm}$ (variant 4 ) and adhesive-rivet joints with an adhesive layer and two longitudinally arranged rivets with an overlap length of $1 \mathrm{z}=20 \mathrm{~mm}$ (variant 9). The lowest mean shear strength was obtained for rivet joints with one rivet and a $12 \mathrm{~mm}$ overlap (variant 3 ). To unequivocally establish the similarities and discrepancies between the experimentally obtained strength values of the assembly joints, the results were analyzed statistically.

\section{STATISTICAL ANALYSIS OF TEST RESULTS}

Strength is an important evaluation criterion of the quality of assembly joints. Shear strength is defined as shear strain produced in a body as a result of tangential stress. The results of the strength tests were analyzed statistically at a confidence level $\alpha=0.05$.

First, we tested the assumption of normal distribution of the experimental results. The results of the statistical tests are shown in Table 4.

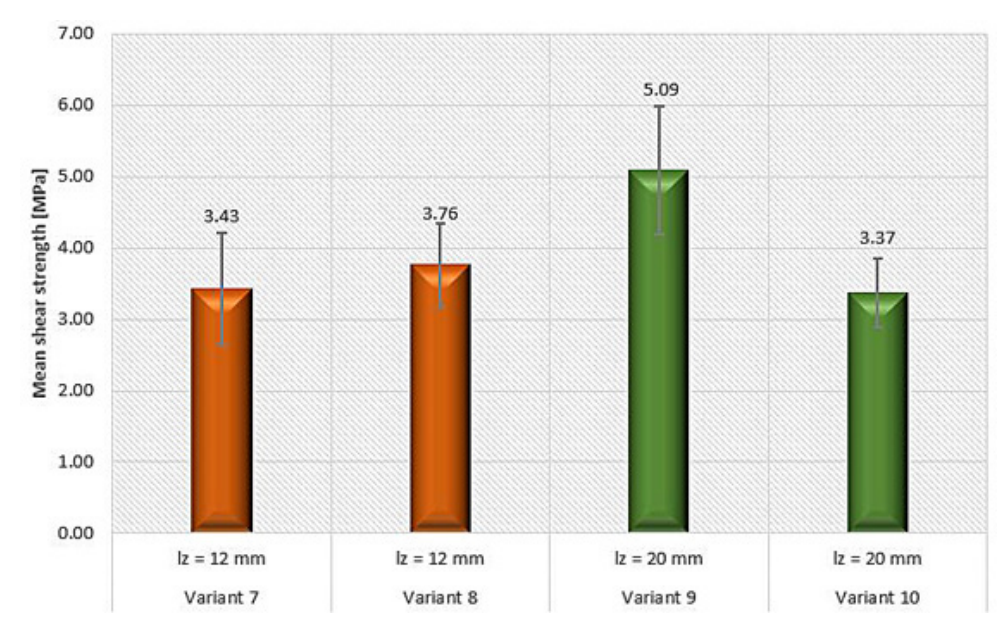

Fig. 6. Mean shear strength of adhesive-rivet joints by overlap length

Table 4. Results of the Shapiro-Wilk W test of normality

\begin{tabular}{|c|c|c|c|c|}
\hline Joint variant & $\begin{array}{c}\text { Sample size, } \\
\text { N }\end{array}$ & $\begin{array}{c}\text { Shapiro-Wilk Statistic, } \\
\text { W }\end{array}$ & $\begin{array}{c}\text { Probability level, } \\
p\end{array}$ & Normality of distribution \\
\hline Variant 1 & 8 & 0.946859 & 0.679546 & YES \\
\hline Variant 2 & 8 & 0.927399 & 0.492713 & YES \\
\hline Variant 3 & 8 & 0.965495 & 0.860502 & YES \\
\hline Variant 4 & 8 & 0.762805 & 0.011304 & YES \\
\hline Variant 5 & 8 & 0.944633 & 0.657160 & YES \\
\hline Variant 6 & 8 & 0.943198 & 0.642797 & YES \\
\hline Variant 7 & 8 & 0.904768 & 0.318687 & YES \\
\hline Variant 8 & 8 & 0.902085 & 0.301668 & NO \\
\hline Variant 9 & 8 & 0.738065 & 0.006022 & YES \\
\hline Variant 10 & 8 & 0.847817 & 0.090532 & \\
\hline
\end{tabular}


Table 5. Results of Kruskal-Wallis test for shear strength of the assembly joints

\begin{tabular}{|c|c|c|c|c|c|c|c|c|c|c|}
\hline \multirow{2}{*}{$\begin{array}{c}\text { Dependent variable: } \\
\text { shear strength } \\
\text { [MPa] }\end{array}$} & \multicolumn{7}{|c|}{ P-value for multiple (two-sided) comparisons; Shear strength [MPa] Kruskal-Wallis test: } \\
\cline { 2 - 12 } & $\begin{array}{c}\text { Variant } \\
1\end{array}$ & $\begin{array}{c}\text { Variant } \\
2\end{array}$ & $\begin{array}{c}\text { Variant } \\
3\end{array}$ & $\begin{array}{c}\text { Variant } \\
4\end{array}$ & $\begin{array}{c}\text { Variant } \\
5\end{array}$ & $\begin{array}{c}\text { Variant } \\
6\end{array}$ & $\begin{array}{c}\text { Variant } \\
7\end{array}$ & $\begin{array}{c}\text { Variant } \\
8\end{array}$ & $\begin{array}{c}\text { Variant } \\
9\end{array}$ & $\begin{array}{c}\text { Variant } \\
10\end{array}$ \\
\hline Variant 1 & & 1.0000 & 0.0005 & 1.0000 & 0.0629 & 1.0000 & 1.0000 & 1.0000 & 1.0000 & 1.0000 \\
\hline Variant 2 & 1.0000 & & 1.0000 & 0.0562 & 1.0000 & 1.0000 & 1.0000 & 1.0000 & 0.0281 & 1.0000 \\
\hline Variant 3 & 0.0005 & 1.0000 & & 0.0000 & 1.0000 & 0.0860 & 0.3379 & 0.0239 & 0.0000 & 0.4927 \\
\hline Variant 4 & 1.0000 & 0.0562 & 0.0000 & & 0.0014 & 1.0000 & 0.3433 & 1.0000 & 1.0000 & 0.2320 \\
\hline Variant 5 & 0.0629 & 1.0000 & 1.0000 & 0.0014 & & 1.0000 & 1.0000 & 1.0000 & 0.0006 & 1.0000 \\
\hline Variant 6 & 1.0000 & 1.0000 & 0.0860 & 1.0000 & 1.0000 & & 1.0000 & 1.0000 & 0.6769 & 1.0000 \\
\hline Variant 7 & 1.0000 & 1.0000 & 0.3379 & 0.3433 & 1.0000 & 1.0000 & & 1.0000 & 0.1896 & 1.0000 \\
\hline Variant 8 & 1.0000 & 1.0000 & 0.0239 & 1.0000 & 1.0000 & 1.0000 & 1.0000 & & 1.0000 & 1.0000 \\
\hline Variant 9 & 1.0000 & 0.0281 & 0.0000 & 1.0000 & 0.0006 & 0.6769 & 0.1896 & 1.0000 & & 0.1252 \\
\hline Variant 10 & 1.0000 & 1.0000 & 0.4927 & 0.2320 & 1.0000 & 1.0000 & 1.0000 & 1.0000 & 0.1252 & \\
\hline
\end{tabular}

Because in a few cases the calculated probability level was lower than the adopted significance level $\alpha=0.05$, which meant that the assumption of normality was not met, non-parametric tests were used in further analysis. The Kruskal-Wallis test was performed, which is the nonparametric counterpart of ANOVA. This test is used to compare means among multiple groups and multiple samples. In the present study, multiple comparisons of mean ranks were made for all samples. The results of this test are shown in Table 5 .

The calculated significance level for the Kruskal-Wallis test was 0.0000 , which was lower than the adopted significance level $\alpha=0.05$. This means that mean shear strength values differed significantly between the individual variants of assembly joints. Significant differences between groups are marked in red in Table 4. Such differences were observed between the following pairs of variants: variant 1 - variant 3 , variant 2 - variant 9 , variant 3 - variant 4 , variant 3 - variant 8 , variant 3 - variant 9 , variant 4 - variant 5 , and variant 5 - variant 9 . This means that there were statistically significant differences between the mean strengths of these joints at the adopted level of significance $\alpha=0.05$.

\section{CONCLUSIONS}

The experimental tests were carried out to compare selected strength parameters of singlelap adhesive, rivet, and adhesive-rivet joints. All the joints were made using aluminum alloy EN AW-2024. In adhesive joints, the length of the overlap was a variable factor. In rivet and adhesive-rivet joints, apart from overlap length, rivet arrangement was also varied.

The analysis of the results leads to the following conclusions:

1. In the case of adhesive joints, joints with an overlap length of $\mathrm{lz}=12 \mathrm{~mm}$ (variant 1 ) are characterized by greater shear strength, however, statistical analysis did not show significant differences at the adopted significance level $\alpha=0.05$.

2. The highest strength among the rivet joints was observed for joints with an overlap length of $\mathrm{lz}=12 \mathrm{~mm}$ and two transversely arranged rivets (variant 4). The statistical analysis of the results obtained in this group of rivet joints indicates that their strength is much higher compared to rivet joints with one rivet and an overlap length $\mathrm{lz}=12 \mathrm{~mm}$ (variant 3) and joints with two rivets arranged longitudinally and an overlap length $\mathrm{lz}=20 \mathrm{~mm}$ (variant 5).

3. Among all the tested joints, the best strength results were obtained for adhesive-rivet joints with an overlap length of $\mathrm{lz}=20 \mathrm{~mm}$ with two longitudinally arranged rivets (version 9). However, this value does not differ significantly from the other variants of adhesive-rivet joints at the adopted significance level $\alpha=0.05$.

Summing up the test results, it can be concluded that bonding with the adhesive had a positive effect on the strength of single-lap adhesiverivet joints with an overlap length of $1 \mathrm{z}=20 \mathrm{~mm}$ fastened with two longitudinally arranged rivets, as shown by the significant differences observed 
in the Kruskal-Wallis test. Changes in the technological parameters of assembly joints, such as overlap length or rivet arrangement, have a significant impact on the strength properties of these joints. It is important to consider the unfavorable stresses occurring during the formation of such joints, especially in the case of adhesive-rivet joints. In hybrid joints, these stresses mainly occur during drilling and riveting of a previously made adhesive joint. Perhaps a change in the technology of making such joints would yield more favorable results. The findings reported in this article are part of our current research on hybrid joints. These results and conclusions can be of help in the design of assembly joints, especially hybrid joints.

\section{REFERENCES}

1. Arenas J.M., Narbón J.J., Alía C. Optimum adhesive thickness in structural adhesives joints using statistical techniques based on Weibull distribution. International Journal of Adhesion and Adhesives, (3)30, 2010, 160-165.

2. Bazrov B.M. Classification of joints. Russian Engineering Research, (4)30, 2010, 399-403.

3. Bijak-Żochowski M., Dietrich M., Kacperski T., Stupnicki J., Szala J., Witkowski J. Podstawy konstrukcji maszyn. Wydawnictwo WNT, 2015.

4. Boś P., Chodorowska D., Fejkiel R., Sitarz S., Wrzask Z. Podstawy konstrukcji maszyn. Wydawnictwa Komunikacji i Łączności, 2017.

5. Derewonko A., Godzimirsk, J., Kosiuczenko K., Niezgoda T., Kiczko A. Strength assessment of adhesive-bonded joints. Computational Materials Science, (1)43, 2008, 157-164.

6. Ebnesajjad S. Adhesives technology handbook. William Andrew Pub, 2008.

7. Godzimirski J. Structural Bonding Problems. Technologia i Automatyzacja Montażu, 1, 2009, 25-31.

8. Habenicht G. Applied adhesive bonding: a practical guide for flawless results. WILEY-VCH, 2009.
9. Higgins A. Adhesive bonding of aircraft structures. International Journal of Adhesion and Adhesives, (5)20, 2000, 367-376.

10. Marques E.A.S., da Silva L.F.M., Banea M.D., Carbas R.J.C. Adhesive Joints for Low- and HighTemperature Use: An Overview. The Journal of Adhesion. (91)7, 2015, 556-585.

11. Miturska I., Rudawska A. Mechanical properties of selected epoxy adhesives. Informatyka, Automatyka, Pomiary w Gospodarce i Ochronie Środowiska, 7(4), 2017, 88-91.

12. Rudawska A. Influence of the Thickness of Joined Elements on Lap Length of Aluminium Alloy Sheet Bonded Joints. Advances in Science and Technology Research Journal, 9, 2015, 35-44.

13. Sadowski T. Zarzeka-Raczkowska E. Hybrid Adhesive Bonded and Riveted Joints - Influence of Rivet Geometrical Layout on Strength of Joints / Połączenia Hybrydowe Klejowo-Nitowe - Wpływ Geometrii Rozmieszczenia Nitów Na Wytrzymałość Połączeń. Archives of Metallurgy and Materials, 57(4), 2012, 1127-1135.

14. Seth A., Vance J.M., Oliver J.H. Virtual reality for assembly methods prototyping: a review. Virtual Reality, 15(1), 2011, 5-20.

15. Silva L.F.M., Öchsner A. Modeling of adhesively bonded joints. Springer, 2008.

16. Silva L.F.M., Pirondi, A. Hybrid adhesive joints. Springer, 2011.

17. Taib A.A., Boukhili R., Achiou S., Gordon S., Boukehili H. Bonded joints with composite adherends. Part I. Effect of specimen configuration, adhesive thickness, spew fillet and adherend stiffness on fracture. International Journal of Adhesion and Adhesives. 26(4), 2006, 226-236.

18. BS EN 4400-2:2019 standard - Aerospace series. Aluminium and aluminium- and magnesium- alloys. Technical specification. Aluminium and aluminium alloy sheet and strip.

19. http://www.aerospacemetals.com/aluminum-distributor.html [access date: 12.12.2019]

20. PN-EN 573-1:2006 standard - Aluminium and aluminium alloys - Chemical composition and types of plasticised products. 